Mini-review

\title{
HIV co-receptor inhibitors as novel class of anti-HIV drugs
}

\author{
Dominique Schols \\ Rega Institute for Medical Research, Katholieke Universiteit Leuven, Minderbroedersstraat 10, B-3000 Leuven, Belgium \\ Received 16 February 2006; accepted 11 April 2006
}

Dedicated to Prof. Erik De Clercq on the occasion of reaching the status of Emeritus-Professor at the Katholieke Universiteit Leuven in September 2006.

\begin{abstract}
Entry inhibitors constitute a new class of drugs to treat infection by human immunodeficiency virus type 1 (HIV-1). The first member of this class, enfuvirtide, previously known as T-20 and targeting gp41, has now been licensed for therapeutic use. Several other entry inhibitors are in various stages of pre-clinical or clinical development. In this review we focus on the chemokine receptor inhibitors targeting CCR5 and CXCR4 that are the main HIV co-receptors for viral entry.
\end{abstract}

(C) 2006 Elsevier B.V. All rights reserved.

Keywords: CCR5; CXCR4; Antagonist; HIV; Chemokine receptor; gp120 Envelope

\section{Contents}

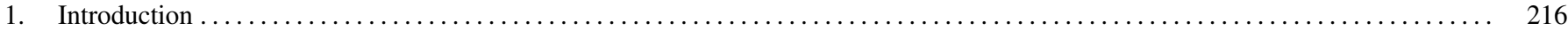

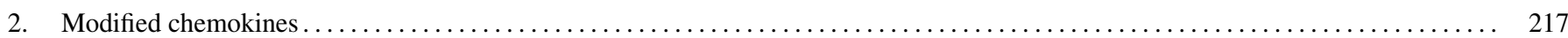

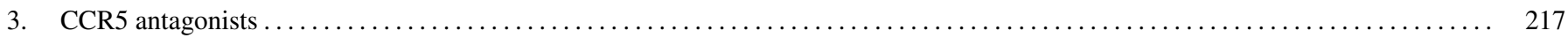

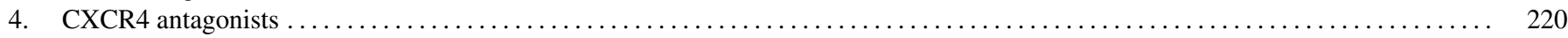

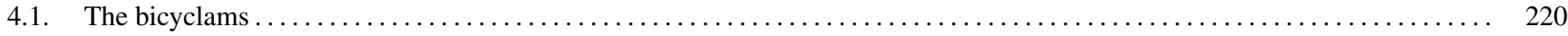

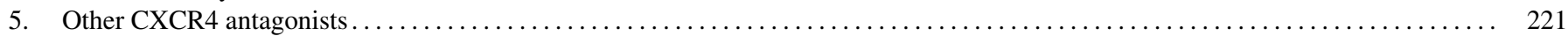

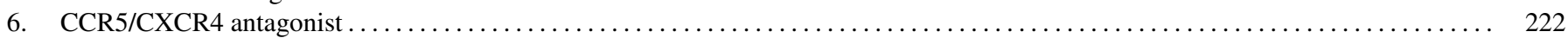

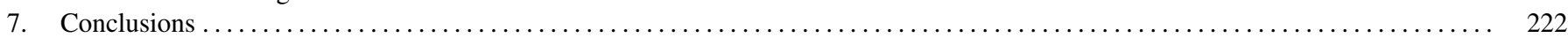

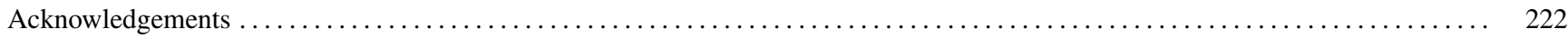

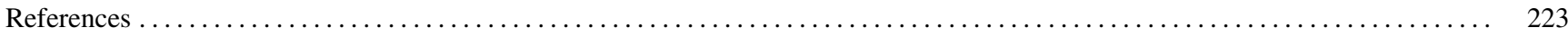

\section{Introduction}

A decade ago now, the chemokine receptors CCR5 and CXCR4 were identified as the major co-receptors for HIV-1 entry, besides the cellular CD4 receptor (Cocchi et al., 1995; Bleul et al., 1996; Feng et al., 1996; Oberlin et al., 1996; Wu et al., 1996; Doranz et al., 1997a,b; Berson et al., 1996; Alkhatib et al., 1996; Dragic et al., 1996; Deng et al., 1996; Trkola et al., 1996). Chemokine receptors are members of the rhodopsin or serpentine receptor superfamily. These are $\mathrm{G}$ protein-coupled seven transmembrane (7TM) receptors (GPCR), containing an acidic extracellular N-terminal domain, 7TM regions and an intracel-

E-mail address: Dominique.schols@ rega.kuleuven.be. lular cytoplasmatic tail. The $\mathrm{N}$-terminal domain is believed to be essential for ligand binding, whereas the C-terminus is important in $\mathrm{G}$ protein activation. The migration and activation of leukocytes during normal and inflammatory processes is controlled by the natural ligands of these receptors, the chemotactic cytokines or chemokines (Baggiolini, 1998). To date, 6 CXC(CXCR1-6), and 10 CC-chemokine receptors (CCR1-10), 1 $\mathrm{XC}$ - and $1 \mathrm{CX}_{3} \mathrm{C}$-chemokine receptor are identified (Murphy, 2002).

Ever since, CCR5 and CXCR4 are discovered as co-receptors for HIV-1 entry, these receptors were subject of many studies showing their importance in the transmission and pathogenesis of HIV. The observation that the natural ligands of these receptors (RANTES, MIP-1 $\beta$, LD78 $\beta$, MIP- $1 \alpha$ and SDF-1) and also some specific monoclonal antibodies against certain epi- 
topes of these receptors possess anti-HIV-1 activity, made these chemokine receptors attractive novel targets for future anti-HIV therapy (Cocchi et al., 1996). This idea was further supported by the fact that people with a homozygeous 32 basepair deletion in the CCR5 gene (CCR5 delta32/delta32), that is decoded in a premature receptor protein that remains intracellular, show a complete normal phenotype and are relatively resistant against HIV-1 infection (Samson et al., 1996; Liu et al., 1996; Dean et al., 1996). However, HIV-1 infection in CCR5 -/- individuals, although rare, has been documented and the viral quasispecies from these individual throughout disease is exclusively using CXCR4 (Michael et al., 1998; Naif et al., 2002).

The appearance of $\mathrm{X} 4$ viruses is associated with accelerated $\mathrm{CD} 4^{+} \mathrm{T}$-cell decline and clinical progression towards AIDS (Connor et al., 1997; Penn et al., 1999; Schramm et al., 2000; Jekle et al., 2002, 2003). It is hypothesized that certain mutations in the V3 loop of the viral envelope glycoprotein are strongly associated with the shift from R5 viruses to X4 viruses. In particular, basic amino acids at the V3 loop positions 11 and 25 very frequently distinguish X4 from R5 viruses (Fouchier et al., 1992; Cocchi et al., 1996). The actual mutational pathway is as yet unexplored. In addition, it is known that dual-tropic $\mathrm{R} 5 / \mathrm{X} 4$ viruses also emerge around the time of R5 to X4 transition, but also their evolutionary role is not certain (Connor et al., 1997; Scarlatti et al., 1997). Some groups demonstrated that progression from $\mathrm{R} 5$ to $\mathrm{X} 4$ occurred via an intermediate that has dual-tropic (R5/X4) or even multi-tropic co-receptor usage such as CCR5, CCR3, CCR2b and CXCR4 (Hu et al., 2000). It is believed that cellular and humoral components of the immune system cause selective pressure that results in diversification in gp120 and alterations in co-receptor usage, but this remains largely unexplored.

Initially, it was investigated using chemokines as antiretroviral therapeutics, but this was restrained because of their short half-life $(<10 \mathrm{~min})$ and potential inflammatory side effects of the chemokines. Thereby, chemokines do not invariably act as HIV-suppressive agents. For instance, SDF-1 has been demonstrated to increase the infectivity of CCR5-using (R5) strains at the transcriptional level, while blocking the infection of CXCR4 (X4) strains at the entry level (Marechal et al., 1999). In addition, it has also been observed that CC-chemokines can enhance HIV-1 infection in vitro in some systems, probably due to chemokine-induced cell activation (Gordon et al., 1999; Kelly et al., 1998; Marozsan et al., 2001). Moreover, CC-chemokines might drive the evolution of less pathogenic R5 viruses to the more pathogenic X4 viruses (Mosier et al., 1999; Trkola et al., 1999).

\section{Modified chemokines}

To overcome these limitations, new chemokine inhibitors have been designed, derived from the natural CCR5 and CXCR4 ligands. These modified chemokines should interact with the receptor and prevent HIV-1 infection by blocking relevant epitopes and/or inducing receptor internalisation without inducing signaling. RANTES (3-68) is such a processed form of RANTES that lacks two N-terminal residues (Schols et al., 1998a). By this truncation the chemokine loses its agonistic actvity, but shows the ability to potently block R5 viruses in an antagonistic manner (Schols et al., 1998a; Proost et al., 1998). A synthetic truncated form of RANTES, i.e. RANTES(9-68), lacking eight amino acids at its $\mathrm{N}$-terminus, also was antagonistic but less potently inhibited R5 HIV-1 strains than RANTES(3-68) (Schols et al., 1998a; Proost et al., 1998; Arenzana-Seisdedos et al., 1996). Several derivatives of RANTES that bind to CCR5 and inhibit infection of lymphocytes and cells of the macrophage lineage with R5 viruses have been identified. Aminooxypentane (AOP)RANTES was created by chemical modification of the aminoterminus. This derivative has been found to decrease HIV-1 infectivity in many cell types and showed reduced capacity to induce chemotaxis. In addition, like intact RANTES it induced downmodulation of surface CCR5 to early endosomes. However, AOP-RANTES also prevented the recycling of CCR5 to the cell surface resulting in a long-lasting depletion of CCR5 (Mack et al., 1998). Comparable results were obtained with the $\mathrm{N}$-nanoyl (NNY)-RANTES derivative that also reduced proinflammatory signaling through its interaction with CCR5 (Simmons et al., 1997). Extension of human RANTES by a single residue at the amino terminus also proved sufficient to produce a potent and selective antagonist. Methionylated RANTES (Met-RANTES) was fully folded but completely inactive in calcium mobilisation and chemotaxis assays with the monocytic cell line THP-1 and antagonized the RANTES-and MIP- $1 \alpha$-induced chemotaxis in these cells and in primary T-cells. Its antagonistic effect was selective since Met-RANTES had no effect on IL-8-or MCP1-induced responses in these cells (Proudfoot et al., 1996). Another RANTES analog, by changing the first three aminoterminal amino acids of the native protein with a nonanoyl, thioproline and clyclohexylglycine, called PSC-RANTES, showed potent anti-HIV activity against R5 viruses in vitro and was also capable of preventing vaginal SHIV transmission in rhesus macaques (Lederman et al., 2004). As LD78 $\beta$ is the most active natural CCR5 agonist and the most potent chemokine to suppress R5 HIV-1 infection (Menten et al., 1999; Aquaro et al., 2001), the aminooxypentane-linked variant of LD78 $\beta$, termed AOP-LD78 $\beta$ is about 10 -fold more active than AOPRANTES at inhibiting HIV infection, making it the most effective chemokine-based HIV inhibitor described to date (Townson et al., 2000).

However, because these derivatives, like the chemokines they are derived of, also are predicted to have inflammatory side effects when used therapeutically, new classes of antagonistic compounds were designed to effectively block HIV-1 infection, i.e. small-molecule compounds, peptides and monoclonal antibodies. The primary mechanism of co-receptor antagonist function does not rely on receptor down-modulation, but on receptor occupancy. Such inhibitors are unable to induce signaling and therefore implausible to indirectly augment virus replication or to induce inflammation.

\section{CCR5 antagonists}

The first low molecular weight CCR5 antagonist with antiviral activity that was described was TAK-779 $(N, N$-dimethyl- $N$ - 
[4-[ [ [2-( 4-methylphenyl )-6,7-dihydro-5H-benzocyclohepten8-yl ]carbonyl ]amino ]benzyl ]tetrahydro-2H - pyran - 4-ammonium chloride) (Takeda Chemicals) (Fig. 1; Baba et al., 1999). It was shown to inhibit R5, but not X4, virus replication with laboratory-adapted strains and clinical isolates without activat- ing or down regulating CCR5. The compound did not inhibit the binding of RANTES, eotaxin, TARC or SDF-1 to, respectively, CCR1-, CCR3-, CCR4-or CXCR4-transfected cells. However, TAK-779 inhibited the binding of MCP-1 to CCR2b-transfected cells. It was further demonstrated that the binding of TAK-779<smiles>Cc1ccc(-c2ccc3c(c2)C=C(C(=O)Nc2ccc(C[N+](C)(Cl)C4CCOCC4)cc2)CCC3)cc1</smiles><smiles>CCON=C(c1ccc(Br)cc1)C1CCN(C2(C)CCN(C(=O)c3c(C)cc[n+]([O-])c3C)CC2)CC1</smiles><smiles>CCCCN1C(=O)C(C(O)C2CCCCC2)NC(=O)C12CCN(Cc1ccc(Oc3ccc(C(=O)O)cc3)cc1)CC2</smiles><smiles>COC[C@@H](c1ccc(C(F)(F)F)cc1)N1CCN(C2(C)CCN(C(=O)c3c(C)ncnc3C)CC2)CC1C</smiles><smiles>Cc1nnc(C(C)C)n1C1CC2CCC([C@H]2C)[C@H]1NCCC(NC(=O)C1CCC(F)(F)CC1)c1ccccc1</smiles>

UK-427,857<smiles>CCCCOCCOc1ccc(-c2ccc3c(c2)/C=C(/C(=O)Nc2ccc(S(=O)Cc4cncn4CCC)cc2)CCCN3CC(C)C)cc1</smiles>

TAK-652<smiles>CC(=O)N1CCC(C(=O)N(CCCN2CCC(Cc3ccc(C(N)=O)cc3)CC2)c2ccc(C)c(Cl)c2)CC1</smiles>

Fig. 1. Chemical structures of several small molecule CCR5 antagonists: TAK-779, TAK-652, TAK-220 (all from Takeda Chemicals), SCH-C (SCH-351125) (Schering-Plough), SCH-D (vicriviroc, SCH-417690) (Schering-Plough), UK-427,857 (maraviroc, Pfizer Inc) and GW873140 (aplaviroc, Ono Pharmaceutical/Glaxo Smith Kline). 
and interaction with CCR5 can be assigned to a cavity formed between transmembrane helices 1-3 and 7 near the extracellular surface of the receptor (Dragic et al., 2000). TAK-779 could not be developed as an anti-HIV-1 drug because of its variable anti-HIV-1 activity and of its poor oral bioavailability. Recently, two novel CCR5 antagonists from Takeda Chemicals were described, namely TAK-220 and TAK-652 (Takashima et al., 2005; Baba et al., 2005). TAK-220 EC 50 values ranged from 0.5 to $1.7 \mathrm{nM}$ against R5 isolates in PBMCs and from 2.9 to $34 \mathrm{nM}$ against various R5 HIV-1 clades (Takashima et al., 2005). At a dose of $5 \mathrm{mg} / \mathrm{kg}$, TAK-220 showed oral availabilities of 9.5 and $28.9 \%$ in rats and monkeys, respectively. In contrast to TAK-779, TAK-220 did not inhibit the binding of MIP-1 $\beta$ to CCR5-transfected cells and had no effect on MIP-1 $\beta$-induced chemotaxis (Takashima et al., 2005). The other CCR5 antagonist, TAK-652 was active against all R5 isolates (clades A-G) $\left(\mathrm{EC}_{50}\right.$ values ranging from 0.5 to $2.4 \mathrm{nM}$ ) evaluated so far, but as TAK-779 it inhibited the binding of MCP-1 to CCR2bexpressing cells. These three CCR5 antagonists were not active against the dual-tropic (R5/X4) HIV-1 strain HE, when evaluated in PBMCs. The authors reported a significant variability among the oral absorption levels of TAK-652 in animals, but no details were provided. However, an exploratory phase I trial was attempted to evaluate the safety, tolerability and pharmacokinetics in humans. A single oral dose of TAK-652 up to $100 \mathrm{mg}$ was safe and well tolerated in humans. The compound displayed favorable pharmacokinetics and its plasma concentration was $9.1 \mathrm{nM}$ even $24 \mathrm{~h}$ after the administration of $25 \mathrm{mg}$. Further trials are ongoing to determine safety and pharmacokinetics during consecutive administration of TAK-652.

Two years after the publication of the TAK-779 paper, a novel compound called SCH-C (Schering-Plough) was described as a potent CCR5 antagonist (Strizki et al., 2001). The compound, also designated $\mathrm{SCH}-351125$, is an oxime-piperidine compound with potent activity against R5 HIV-1 strains in U87.CD4 cells transfected with CCR5, but not against X4 strains in CXCR4expressing cells (Fig. 1). As shown by multiple receptor binding and signal transduction assays, $\mathrm{SCH}-\mathrm{C}$ is a highly specific CCR5 antagonist with no interaction with other known chemokine receptors (Strizki et al., 2001). In addition, SCH-C was demonstrated to have broad and potent antiviral activity against primary $\mathrm{R} 5$ isolates in vitro and showed a favorable pharmacokinetic profile in rodents and primates. Later, $\mathrm{SCH}-\mathrm{C}$ has shown in vivo antiviral efficacy in clinical studies by reducing the plasma viremia in R5 HIV-1-infected persons (Reynes et al., 2002a,b). $\mathrm{SCH}-\mathrm{C}$ reduced plasma viral RNA titers in HIV-infected patients by $1.5 \operatorname{logs}$ when dosed orally at $100 \mathrm{mg}$ twice daily for 10 days, thus validating CCR5 as a target for intervention against HIV infection. However, this compound caused a modest, but dosedependent prolongation of the cardiac QT interval (Reynes et al., 2002a,b).

Then a derivative of SCH-C, SCH-D or SCH-417690 was presented as a novel CCR5 inhibitor (Fig. 1; Schurmann et al., 2004). This compound is about 2 - to 40 -fold more potent against a panel of primary $\mathrm{R} 5$ isolates compared with $\mathrm{SCH}-\mathrm{C}$, and is viral genotype independent (Strizki et al., 2005). SCH-D was also highly active against a clade G Russian isolate (RU570)
$\left(\mathrm{EC}_{50}: 1.2 \mathrm{nM}\right)$, which previously was shown to be insensitive to $\mathrm{SCH}-\mathrm{C}\left(\mathrm{EC}_{90}>1 \mu \mathrm{M}\right)$. Recently, in vitro generated resistant viruses against SCH-D were described (Marozsan et al., 2005). Again these viruses retained the R5 phenotype and could not replicate in PBMCs derived from donors homozygous for the CCR5 delta32 allele. However, one of the resistant viruses was capable of replication in U87.CD4.CXCR4 cells and was sensitive to AMD3100. Thus, perhaps some $\mathrm{X} 4$ variants were present in this escape mutant swarm which were not detected in the original virus isolate. SCH-D, now named vicriviroc, has improved antiviral potency and better pharmacology properties compared to its predecessor SCH-C (Strizki et al., 2005), and is in clinical development and undergoing phase 3 clinical trials (Dunkle et al., 2005).

Two other recently described CCR5 antagonists are GW873140, a spiroketopiperazine based agent (Ono Pharmaceutical/Glaxo Smith Kline) (Maeda et al., 2001, 2003) and UK-427,857 (Pfizer) (Fig. 1; Napier et al., 2003). Both compounds exerted potent antiviral activity against a wide spectrum of R5 laboratory strains and primary isolates and revealed favorable oral bioavailability.

GW873140 was named aplaviroc and demonstrated antiviral activity and acceptable safety in a short-term study of HIVinfected subjects. However, in four patients in two phase $2 \mathrm{~b}$ studies with aplaviroc developed clinical changes in liver function tests and studies have been terminated in treatment-negative individuals due to the concern of the hepatic safety signals (Nichols et al., 2005).

The UK-427,857 compound is now named maraviroc and studies in healthy volunteers demonstrated that it is well tolerated at doses up to and including $300 \mathrm{mg}$ BID (Dorr et al., 2005). Short-term monotherapy studies were conducted in HIVinfected persons to evaluate the effect on viral load, and the relationship between viral load reduction and PK/PD parameters. In total of 79 patients with $>5000$ copies/ml CCR5-using $\mathrm{HIV}$, and with CD 4 counts $>250$ cells $/ \mathrm{mm}^{3}$ received maraviroc or placebo for 10 days and were followed up until day 40. All patients receiving maraviroc at doses of $200 \mathrm{mg}$ daily had a viral load reduction of $>1.0->1.5 \log _{10}$. (Fatkenheuer et al., 2005; van der Ryst et al., 2005). Plasma concentrations of maraviroc were similar to those seen in healthy volunteers and reduction in viral load at day 11 correlated with systemic exposure. The compound was tolerated at all doses and was not associated with any changes in liver function tests (van der Ryst et al., 2005). Emergence of dual/mixed-tropic virus was seen in two patients which was a transient emergence on day 11 in one patient, while in the second patient the dual/mixed-tropic virus persisted. Maraviroc is currently in phase $2 \mathrm{~b} / 3$ clinical trails for the treatment of HIV infection at doses equivalent to $300 \mathrm{mg}$ BID.

Anti-CCR5 co-receptor mAb that inhibit HIV-1 entry represent another class of blocking HIV agents that are reported. PRO 140 (Progenics Pharmaceuticals, NY) is a specific anti-CCR5 $\mathrm{mAb}$ that potently inhibits HIV-1 entry at a concentration that does not affect CCR5 chemokine receptor activity and showed to be genetic-subtype-independent (Olson et al., 1999; Trkola et al., 2001). Another study also showed that PRO 140 was able to control HIV-1-infection in the in the human peripheral blood lym- 
phocytes/severe combined immunodeficiency (hu-PBL-SCID) mouse model (Franti et al., 2004). Recently, PRO 140 was evaluated in a clinical phase I study by intravenous infusion to healthy male subjects to examine the safety, pharmacokinetics, and pharmacodynamic effects of single dosing (Olson et al., 2006). Individuals were treated with $0.1,0.5,2.0$ and $5.0 \mathrm{mg} / \mathrm{kg}$ PRO 140 in sequential dose-rising cohorts of five subjects each and evaluated for 60 days post-treatment. No infusion-related toxicities, no drug-related site-effects and no changes in electrocardiograms were observed. The CCR5 lymphocytes were coated for $>60$ days with a dose of $5 \mathrm{mg} / \mathrm{kg}$ of PRO 140 and no changes were observed in plasma RANTES. According to the authors these finding support further development of PRO 140 as a novel and long acting therapy of HIV infection (Olson et al., 2006).

\section{CXCR4 antagonists}

\subsection{The bicyclams}

In the search for new anti-HIV agents with better characteristics than the existing drugs (reverse transcriptase inhibitors at that time), a class of compounds was discovered with potent and selective anti-HIV activity, namely the bicyclams (De Clercq

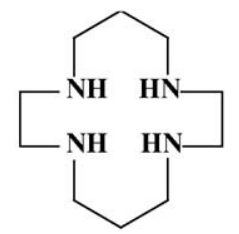

AMD1498

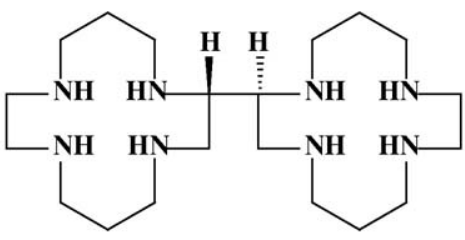

AMD1657 et al., 1992). The prototype compound used for the development of these new agents was the monocyclam AMD1498 (1,4,8,11-tetraazacyclotetradecane), which itself was active at concentrations up to $400 \mu \mathrm{M}$, with a selectivity index of $>5$ (Fig. 2). AMD1498 was part of a project aimed at making new anti-HIV compounds that would gain anti-HIV activity by the formation of metal complexes using organic molecules, possible by the presence of four nitrogens in the centre of the cyclam ring. The bicyclams exist of two such macrocyclic rings, containing 12-14 members each, linked in various ways (De Clercq et al., 1992). Two compounds, designated AMD1657 and AMD2763, were found active against HIV-1 and HIV-2 at a concentration of $0.14-1.4 \mu \mathrm{M}$, with a selectivity index of $>1000-10000$. In AMD1657 the cyclam moieties were linked with a direct carbon-carbon bridge creating two chiral centres, in AMD2763 via an aliphatic (propylene) bridge (Fig. 2). Further studies pointed out that bicyclam derivatives in which the two monocylam rings are connected by an aromatic linker, in stead of an aliphatic linker, inhibit HIV replication at concentrations of $1-10 \mathrm{nM}$, which is about 100 -fold lower than the concentration required for AMD2763 (De Clercq et al., 1994). The most potent bicyclam of the series and also the prototype is AMD3100, AMD in which the two cyclam moieties are tethered by a 1,4-phenylenebis(methylene)-bridge (Fig. 2) (Bridger

AMD2763

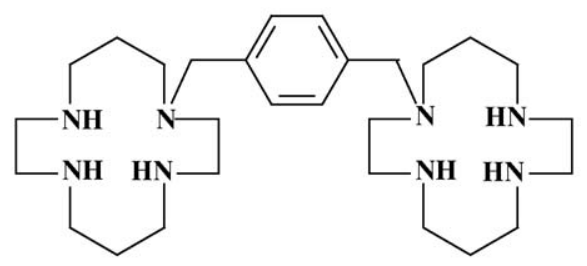

AMD3100<smiles>CC(C)[R14](C)(C)CCC[C@H](NC(=O)c1ccc(CNCc2ccccn2)cc1)C(=O)N[C@@H](C)c1cccc2ccccc12</smiles>

Fig. 2. Chemical structures of several small molecule CXCR4 antagonists: AMD1498, AMD2763, AMD1657 and AMD3100 (AnorMED) and KRH-1636 (Kureha Chemical Industry). 
et al., 1995,1999; De Clercq et al., 1994; Joao et al., 1995). AMD3100 inhibited HIV-1 and HIV-2 replication with an $\mathrm{EC}_{50}$ of $1-10 \mathrm{nM}$ and provided complete protection of monocytes and lymphocytes at $10-30 \mathrm{nM}$. Studies with AMD3100-resistant viruses pointed to gp120 as the possible target molecule for the bicyclams because a number of mutations accumulated in the V3-V4 region of gp120 (De Vreese et al., 1996).

When the M-tropic (R5) and T-tropic (X4) strains were found to interact respectively with the chemokine receptors CCR5 and CXCR4, as main co-receptor (Alkhatib et al., 1996; Berson et al., 1996; Choe et al., 1996; Dragic et al., 1996; Feng et al., 1996), it was immediately shown thereafter by our group that the bicyclam derivatives exhibit their strong and selective antiviral efficacy through their specific interaction with CXCR4 (Schols et al., 1997a,b). Indeed, AMD3100 showed activity against a wide variety of X4 and also R5/X4 HIV strains in PBMCs but not against R5 strains (Schols et al., 1997b; Donzella et al., 1998; Glushakova et al., 1999; Schramm et al., 2000). CXCR4 antagonists such as AMD3100 have a potent antiviral activity against R5/X4 viruses in PBMCs, and this in contrast with R5 inhibitors which are not able to inhibit R5/X4 viruses in these cells. Thus, we can simple state that R5/X4 viruses behave like $\mathrm{X} 4$ viruses in PBMCs. Further studies showed that AMD3100 potently inhibits the intracellular calcium signaling induced by SDF-1, the natural ligand of CXCR4, in many cell types and also the SDF-1-induced chemotaxis and internalisation could be dose-dependently blocked by AMD3100 (Schols et al., 1997a,b; Hatse et al., 2002). Additionally, the chemokine receptor inhibition by AMD3100 is strictly confined to its interaction with CXCR4 and not with any other chemokine receptor (Hatse et al., 2001, 2002). An another interesting observation was that $\mathrm{X} 4$ viruses made resistant to SDF-1 or AMD3100 were able to overcome the inhibitory effects through multiple mutations in gp120, but these resistant viruses still needed CXCR4 (and did not switch to CCR5 or another chemokine receptor) to enter the cells (Schols et al., 1998b). Later on, this observation is also made for CCR5 inhibitor resistant viruses in that these resistant viruses (generated in vitro) do not switch to use CXCR4 (or another chemokine receptor) but still use CCR5 to enter the cells (Trkola et al., 2002; Baba et al., 2005; Dorr et al., 2005; Marozsan et al., 2005). Thus, although gp120 is described as very variable and flexible, the gp120 is very faithful towards its co receptor use.

In two separate studies, pharmacokinetics and antiviral activity of AMD3100 was evaluated in humans (Hendrix et al., 2000, 2004; Schols et al., 2002). AMD3100 was administered for 10 days by continuous intravenous infusion in an open-label, dose escalation study from $2.5 \mu \mathrm{g} / \mathrm{kg} / \mathrm{h}$ up to $160 \mu \mathrm{g} / \mathrm{kg} / \mathrm{h}$ in 40 HIV-infected patients. At the time of the clinical study, NSI/SI phenotype was determined in an MT-2 cell assay. The HIV phenotype was SI $(30 \%)$, NSI (45\%), or not tested $(25 \%)$. One patient $(5 \mu \mathrm{g} / \mathrm{kg} / \mathrm{h})$ had serious and possibly drug-related thrombocytopenia. Two patients ( 40 and $160 \mu \mathrm{g} / \mathrm{kg} / \mathrm{h}$ ) had unexpected, though not serious, premature ventricular contractions. Most patients in the 80 and $160 \mu \mathrm{g} / \mathrm{kg} / \mathrm{h}$ cohorts had paresthesias. Only one patient, the patient whose virus was SI and confirmed to use purely CXCR4, and who received the highest dose studied
$(160 \mu \mathrm{g} / \mathrm{kg} / \mathrm{h})$ had a significant $0.9 \log _{10}$ copies/mL HIV RNA drop at day 11. In conclusion, AMD3100 was the first CXCR4 antagonist to demonstrate a clinical anti-HIV effect and warrants the development of orally bioavailable CXCR4 antagonists for HIV treatment. So although some concerns were raised with regard to the clinical use for long-term treatment of HIV-1 infections, this study proved that blocking the SDF-1/CXCR4 axis is safe and feasible and inhibiting HIV entry would certainly be a very valuable approach.

\section{Other CXCR4 antagonists}

Several other molecules have been described as anti-HIV agents owing their antiviral activity to their specific interaction with CXCR4. For example, some peptidic agents are described with potent antiretroviral activity. A disadvantage of such peptidic compounds is their complex synthesis, which will contribute considerably to a high cost of therapy. Moreover, no orally bioavailable peptidic agents have been described to date so if they were to move into the clinic they must be administered by injection.

For example, T22, $\left\{\mathrm{Tyr}^{5,12}\right.$ Lys $\left.^{7}\right\}$-polyphemusin, is a cationic 18-amino acid peptide, derived from horseshoe crab blood cells that inhibited replication of HIV-1 by specific binding to the N-terminus and two extracellular loops of CXCR4 (Murakami et al., 1997). Studies with a derivative of T22, called T134, demonstrated that this compound efficiently inhibits the replication of an AMD3100-resistant virus strain, suggesting that the binding sites for AMD3100 and T22 only partially overlap (Arakaki et al., 1999), although they both block the binding of the CXCR4-specific mAb 12G5 and the natural ligand SDF-1 to CXCR4. Tamamura et al. (1998) also reported on a second ana$\log$ of T22, the 14-residue peptide called T140, which showed stronger inhibitory activity against HIV-1 entry.

ALX40-4C ( $N$ - $\alpha$-acetyl-nona-D-arginine (Arg) amide) is a (poly)peptide of nine Arg residues stabilized by terminal protection and inclusion of D-amino acids (Doranz et al., 1997a,b). Initially it was characterized as an inhibitor of the HIV-1 Tattrans-activation response element (TAR) interaction (SumnerSmith et al., 1995). ALX40-4C inhibits HIV-1 NL4-3 in the nanomolar range ( IC $_{50}$ of $3 \mathrm{nM}$ ) in the HUT-78 T-cell line and in PBMCs. In addition, it was demonstrated that ALX40-4C inhibited entry of X4, but not R5 HIV-1 strains. ALX40-4C also inhibited primary $\mathrm{R} 5 / \mathrm{X} 4$ virus isolates, but only when cells expressed CXCR 4 alone, while infection of $\mathrm{CCR}^{+} / \mathrm{CXCR} 4^{+}$ double positive cells by R5/X4 virus strains was not inhibited by ALX40-4C. Moreover, addition of ALX40-4C to cells expressing CXCR4 prevented SDF-1-induced changes in intracellular calcium and prevented binding of an anti-CXCR4 mAb, clone 12G5. In addition, Doranz et al. (2001) described that ALX40$4 \mathrm{C}$ was well tolerated in phase I/II clinical trials in humans, but no significant reductions in viral load were noted. Furthermore, ALX40-4C was shown to be an antagonist to APJ, a GPCR that could serve as an alternative co-receptor for HIV- 1 in the central nervous system (Zhou et al., 2003).

CGP64222 is a basic peptoid oligomer of nine residues that inhibits the replication of a wide range of laboratory strains of 
HIV-1 and HIV-2 in MT-4 cells (Daelemans et al., 2000). Besides its activity against Tat/TAR binding (Hamy et al., 1997), the compound was also shown to inhibit HIV infection through a selective interaction with the CXCR4 receptor. This was demonstrated by the fact that CGP64222 proved inactive in MT-4 cells against HIV-1 strains that are resistant to the bicyclams, was inactive against the R5 HIV-1 strain $\mathrm{BaL}$ and the compound inhibited SDF-1-induced calcium signaling (Daelemans et al., 2000).

KRH-1636 (Kureha Chemical Industries) is a small-molecule CXCR4 antagonist that has a potent anti-HIV activity both in vivo and in vitro (Fig. 2). The compound selectively inhibited infection of $\mathrm{X} 4$ virus strains including several clinical isolates without affecting R5 HIV-1. It also inhibited binding of the CXC chemokine, SDF-1, to CXCR4 specifically and subsequent signal transduction. KRH-1636 prevented monoclonal antibodies from binding to CXCR4 without down-modulation of the coreceptor. Moreover, KRH-1636 showed potent antiviral activity in the hu-PBL-SCID mouse model. Furthermore, this compound was absorbed into the blood after intraduodenal administration as judged by anti-HIV-1 activity and liquid chromatography in the plasma of rats (Ichiyama et al., 2003).

AMD070 (AnorMED) is a novel and recently reported orally bioavailable CXCR4 antagonist that potently inhibited X4 viruses at $\mathrm{EC}_{50}$ values varying between $1-15 \mathrm{nM}$ in $\mathrm{T}$ cell lines, CXCR4-transfected cell lines and PBMCs (Schols et al., 2003). The compound has no interaction with any other chemokine receptor examined so far. In healthy volunteers oral dosing of AMD070 (50, 100, 200 and $400 \mathrm{mg}$ ) was well tolerated, well absorbed and demonstrated dose-proportional pharmacokinetics (Stone et al., 2005). The AMD070 concentrations at $12 \mathrm{~h}$ following one $400 \mathrm{mg}$ oral dose stayed well above the in vitro $\mathrm{EC}_{90}$ in all 9 subjects. A phase Ib/IIa trial to evaluate the potential of AMD070 as an anti-HIV drug in HIV-infected patients is currently ongoing.

\section{CCR5/CXCR4 antagonist}

Recently our group presented a CCR5/CXCR4 antagonist, called AMD3451, as the first low-molecular-weight anti-HIV agent with selective CCR5 and CXCR4 receptor, interaction. AMD3451 is an $N$-pyridinylmethyl cyclam analog (Fig. 3) which shows antiviral activity against a wide variety of R5, $\mathrm{R} 5 / \mathrm{X} 4$ and $\mathrm{X} 4$ strains of HIV-1 and HIV-2 $\left(\mathrm{EC}_{50}\right.$ ranging from 1.2 to $26.5 \mu \mathrm{M}$ ) in various T-cell lines, CCR5-or CXCR4transfected cells, PBMCs and monocytes/macrophages (Princen

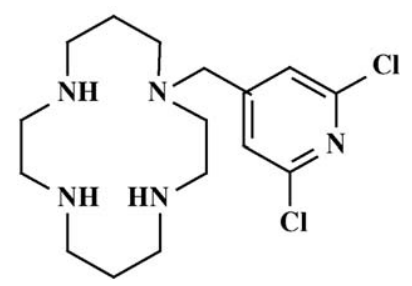

Fig. 3. Chemical structure of the dual CCR5/CXCR4 antagonist AMD3451 (AnorMED). et al., 2004). AMD3451 also inhibited R5, R5/X4 and X4 HIV-1 primary clinical isolates in PBMCs $\left(\mathrm{IC}_{50}: 1.8-7.3 \mu \mathrm{M}\right)$. A PCRbased viral entry assay revealed that AMD3451 blocks R5 and X4 HIV-1 infection at the virus entry stage. AMD3451 dosedependently inhibited the intracellular $\mathrm{Ca}^{2+}$ signaling induced by the CXCR4 ligand SDF-1 in CXCR4-transfected cells, as well as the RANTES-induced $\mathrm{Ca}^{2+}$ flux CCR5-transfected cells. The compound did not interfere with any other chemokine receptor and did not induce by itself intracellular $\mathrm{Ca}^{2+}$ signaling. AMD3451 also inhibited the SDF-1-and MIP-1 $\beta$-induced chemotaxis in a dose-dependent manner and was able to block the SDF-1-and LD78 $\beta$-induced endocytosis in CXCR4-and CCR5-transfected cells. Moreover, studies showed that the compound interacts in a different manner with CXCR4 then the specific CXCR4 antagonist AMD3100 since AMD3451 did not inhibit but enhanced the binding of anti-CXCR4 mAbs (such as clone 12G5) at the cell surface (Princen et al., 2004). The precise interaction sites of AMD3451 with CCR5 and CXCR4 is still under investigation, but it demonstrates that it is possible to develop compounds that interact with both HIV co-receptors. Because of their dual interaction with both CXCR4 and CCR5 and, consequently, their potential to block cellular infection of $\mathrm{R} 5, \mathrm{R} 5 / \mathrm{X} 4$ and $\mathrm{X} 4$ viruses, this class of compounds can be important for the development of an effective anti-HIV microbicide, to slow down viral transmission if these compounds can be used in a gel or in a vaginal ring system.

\section{Conclusions}

New and diverse classes of compounds interfering with the HIV entry process into target cells are approaching clinical application. The antiviral efficacy of the gp 41 fusion inhibitor, T-20 or enfuvirtide, especially when given to HIV-infected subjects harboring drug-resistant viruses and currently having limited therapeutic options, is clearly shown (Chen et al., 2002). In addition, recent clinical studies with a small number of HIV-infected subjects provided proof-of-principle for the antiviral effectiveness of CCR5 and CXCR4 antagonists. As very often mixed populations of viruses may be present in the same patient, CCR5 and CXCR4 antagonists very likely have to be administered in combination to show clinical efficacy. Furthermore, several groups demonstrated synergy not only between viral entry inhibitors and RT or protease inhibitors, but also between different classes of virus entry inhibitors. These promising results will boost the design and development of agents capable of inhibiting HIV binding and subsequent viral entry. Despite the many challenges of safety and clinical application, which are related to the development of such inhibitors, the possible use of these compounds to block HIV infection at a different step in the viral replication cycle will give us new hope to combat viral transmission and AIDS.

\section{Acknowledgements}

The research of the author has been supported by the Flemish "Geconcerteerde Onderzoeksacties" (Krediet no. 05/19), the Flemish "Fonds voor Wetenschappelijk Onderzoek" (Krediet 
no. G-067-04), and the Centers of Excellence of the K.U.Leuven (Krediet no. EF/05/15). The editorial help of Mrs. C. Callebaut and Mrs. I. Aerts is gratefully acknowledged.

\section{References}

Alkhatib, G., Combadiere, C., Broder, C.C., Feng, Y., Kennedy, P.E., Murphy, P.M., Berger, E.A., 1996. CC CKR5: a RANTES, MIP-1 $\alpha$, MIP-1 $\beta$ receptor as a fusion cofactor for macrophage-tropic HIV-1. Science 272, 1955-1958.

Aquaro, S., Menten, P., Struy, F.S., Proost, P., Van Damme, J., De Clercq, E., Schols, D., 2001. The LD78 $\beta$ isoform of MIP- $1 \alpha$ is the most potent CC-chemokine in inhibiting CCR5-dependent human immunodeficiency virus type 1 replication in human macrophages. J. Virol. 75, 4402-4406.

Arakaki, R., Tamamura, H., Premanathan, M., Kanbara, K., Ramanan, S., Mochizuki, K., Baba, M., Fujii, N., Nakashima, H., 1999. T134, a smallmolecule CXCR4 inhibitor, has no cross-drug resistance with AMD3100, a CXCR4 antagonist with a different structure. J. Virol. 73, 1719-1723.

Arenzana-Seisdedos, F., Virelizier, J.L., Rousset, D., Clark-Lewis, I., Loetscher, P., Moser, B., Baggiolini, M., 1996. HIV blocked by chemokine antagonist. Nature 383, 400.

Baba, M., Nishimura, O., Kanzaki, N., Okamoto, M., Sawada, H., Iizawa, Y., Shiraishi, M., Aramaki, Y., Okonogi, K., Ogawa, Y., Meguro, K., Fujino, M., 1999. A small-molecule, nonpeptide CCR5 antagonist with highly potent and selective anti-HIV-1 activity. Proc. Natl. Acad. Sci. U.S.A. 96, 5698-5703.

Baba, M., Takashima, K., Miyake, H., Kanzaki, N., Teshima, K., Wang, X., Shiraishi, M., Iizawa, Y., 2005. TAK-652 inhibits CCR5-mediated human immunodeficiency virus type 1 infection in vitro and has favorable pharmacokinetics in humans. Antimicrob. Agents Chemother. 49, 4584-4591.

Baggiolini, M., 1998. Chemokines and leukocyte traffic. Nature 392, 565-568.

Berson, J.F., Long, D., Doranz, B.J., Rucker, J., Jirik, F.R., Doms, R.W., 1996. A seven-transmembrane domain receptor involved in fusion and entry of T-cell-tropic human immunodeficiency virus type 1 strains. J. Virol. 70, 6288-6295.

Bleul, C.C., Farzan, M., Choe, H., Parolin, C., Clark-Lewis, I., Sodroski, J., Springer, T.A., 1996. The lymphocyte chemoattractant SDF-1 is a ligand for LESTR/fusin and blocks HIV-1 entry. Nature 382, 829-833.

Bridger, G.J., Skerlj, R.T., Thornton, D., Padmanabhan, S., Martellucci, S.A., Henson, G.W., Abrams, M.J., Yamamoto, N., De Vreese, K., Pauwels, R., De Clercq, E., 1995. Synthesis and structure-activity relationships of phenylenebis(methylene)-linked bis-tetraazamacrocycles that inhibit HIV replication. Effects of macrocyclic ring size and substituents on the aromatic linker. J. Med. Chem. 38, 366-378.

Bridger, G.J., Skerlj, R.T., Padmanabhan, S., Martellucci, S.A., Henson, G.W., Struyf, S., Witvrouw, M., Schols, D., De Clercq, E., 1999. Synthesis and structure-activity relationships of phenylenebis(methylene)-linked bisazamacrocycles that inhibit HIV-1 and HIV-2 replication by antagonism of the chemokine receptor CXCR4. J. Med. Chem. 42, 3971-3981.

Chen, R.Y., Kilby, J.M., Saag, M.S., 2002. Enfuvirtide. Expert Opin. Invest. Drugs $11,1837-1843$.

Choe, H., Farzan, M., Sun, Y., Sullivan, N., Rollins, B., Ponath, P.D., Wu, L., Mackay, C.R., LaRosa, G., Newman, W., Gerard, N., Gerard, C., Sodroski, J., 1996. The $\beta$-chemokine receptors CCR3 and CCR5 facilitate infection by primary HIV-1 isolates. Cell $85,1135-1148$.

Cocchi, F., DeVico, A.L., Garzino-Demo, A., Arya, S.K., Gallo, R.C., Lusso, P., 1995. Identification of RANTES, MIP- $1 \alpha$, and MIP-1 $\beta$ as the major HIV-suppressive factors produced by $\mathrm{CD} 8^{+} \mathrm{T}$ cells. Science 270 , $1811-1815$.

Cocchi, F., DeVico, A.L., Garzino-Demo, A., Cara, A., Gallo, R.C., Lusso, P., 1996. The V3 domain of the HIV-1 gp120 envelope glycoprotein is critical for chemokine-mediated blockade of infection. Nat. Med. 2, 1244-1247.

Connor, R.I., Sheridan, K.E., Ceradini, D., Choe, S., Landau, N.R., 1997. Change in coreceptor use coreceptor use correlates with disease progression in HIV-1-infected individuals. J. Exp. Med. 185, 621-628.
Daelemans, D., Schols, D., Witvrouw, M., Pannecouque, C., Hatse, S., van Dooren, S., Hamy, F., Klimkait, T., De Clercq, E., Vandamme, A.M., 2000. A second target for the peptoid Tat/transactivation response element inhibitor CGP64222: inhibition of human immunodeficiency virus replication by blocking $\mathrm{CXC}$-chemokine receptor 4-mediated virus entry. Mol. Pharmacol. 57, 116-124.

De Clercq, E., Yamamoto, N., Pauwels, R., Baba, M., Schols, D., Nakashima, H., Balzarini, J., Murrer, B.A., Schwartz, D., Thornton, D., Bridger, G., Fricker, S., Henson, G., Abrams, M., Picker, D., 1992. Potent and selective inhibition of human immunodeficiency virus (HIV)-1 and HIV-2 replication by a class of bicyclams interacting with a viral uncoating event. Proc. Natl. Acad. Sci. U.S.A. 89, 5286-5290.

De Clercq, E., Yamamoto, N., Pauwels, R., Balzarini, J., Witvrouw, M., De Vreese, K., Debyser, Z., Rosenwirth, B., Peichl, P., Datema, R., 1994. Highly potent and selective inhibition of human immunodeficiency virus by the bicyclam derivative JM3100. Antimicrob. Agents Chemother. 38, 668-674.

De Vreese, K., Kofler-Mongold, V., Leutgeb, C., Weber, V., Vermeire, K., Schacht, S., Anné, J., De Clercq, E., Datema, R., Werner, G., 1996. The molecular target of bicyclams, potent inhibitors of human immunodeficiency virus replication. J. Virol. 70, 689-696.

Dean, M., Carrington, M., Winkler, C., Huttley, G.A., Smith, M.W., Allikmets, R., Goedert, J.J., Buchbinder, S.P., Vittinghoff, E., Gomperts, E., Donfield, S., Vlahov, D., Kaslow, R., Saah, A., Rinaldo, C., Detels, R., O'Brien, S.J., 1996. Genetic restriction of HIV-1 infection and progression to AIDS by a deletion allele of the CKR5 structural gene. Hemophilia Growth and Development Study, Multicenter AIDS Cohort Study, Multicenter Hemophilia Cohort Study, San Francisco City Cohort, ALIVE Study. Science 273, 1856-1862.

Deng, H., Liu, R., Ellmeier, W., Choe, S., Unutmaz, D., Burkhart, M., Di Marzio, P., Marmon, S., Sutton, R.E., Hill, C.M., Davis, C.B., Peiper, S.C., Schall, T.J., Littman, D.R., Landau, N.R., 1996. Identification of a major co-receptor for primary isolates of HIV-1. Nature 381, 661666.

Donzella, G.A., Schols, D., Lin, S.W., Esté, J.A., Nagashima, K.A., Maddon, P.J., Allaway, G.P., Sakmar, T.P., Henson, G., De Clercq, E., Moore, J.P., 1998. AMD3100, a small molecule inhibitor of HIV-1 entry via the CXCR4 co-receptor. Nat. Med. 4, 72-77.

Doranz, B.J., Berson, J.F., Rucker, J., Doms, R.W., 1997a. Chemokine receptors as fusion cofactors for human immunodeficiency virus type 1 (HIV1). Immunol. Res. 16, 15-28.

Doranz, B.J., Grovit-Ferbas, K., Sharron, M.P., Mao, S.H., Goetz, M.B., Daar, E.S., Doms, R.W., O'Brien, W.A., 1997b. A small-molecule inhibitor directed against the chemokine receptor CXCR4 prevents its use as an HIV-1 coreceptor. J. Exp. Med. 186, 1395-1400.

Doranz, B.J., Filion, L.G., Diaz-Mitoma, F., Sitar, D.S., Sahai, J., Baribaud, F., Orsini, M.J., Benovic, J.L., Cameron, W., Doms, R.W., 2001. Safe use of the CXCR4 inhibitor ALX40-4C in humans. AIDS Res. Hum. Retrovir. 17, 475-486.

Dorr, P., Westby, M., Dobbs, S., Griffin, P., Irvine, B., Macartney, M., Mori, J., Rickett, G., Smith-Burchnell, C., Napier, C., Webster, R., Armour, D., Price, D., Stammen, B., Wood, A., Perros, M., 2005. Maraviroc (UK-427,857), a potent, orally bioavailable, and selective small-molecule inhibitor of chemokine receptor CCR5 with broad-spectrum anti-human immunodeficiency virus type 1 activity. Antimicrob. Agents Chemother. 49, 4721-4732.

Dragic, T., Litwin, V., Allaway, G.P., Martin, S.R., Huang, Y., Nagashima, K.A., Cayanan, C., Maddon, P.J., Koup, R.A., Moore, J.P., Paxton, W.A., 1996. HIV-1 entry into CD4+ cells is mediated by the chemokine receptor CC-CKR-5. Nature 381, 667-673.

Dragic, T., Trkola, A., Thompson, D.A., Cormier, E.G., Kajumo, F.A., Maxwell, E., Lin, S.W., Ying, W., Smith, S.O., Sakmar, T.P., Moore, J.P., 2000. A binding pocket for a small molecule inhibitor of HIV-1 entry within the transmembrane helices of CCR5. Proc. Natl. Acad. Sci. U.S.A. $97,5639-5644$

Dunkle, L., Keung, A., Samsone, A., Strizki, J., 2005. Vicriviroc is a novel, potent inhibitor with pharmaceutic, pharmacokinetic and pharmacodynamic (PK/PD) properties that support once daily dosing. In: First 
International Workshop. Targeting HIV Entry, 2-3 December, Bethesda, MD, USA (Abstract 13).

Fatkenheuer, G., Pozniak, A.L., Johnson, M.A., Plettenberg, A., Staszewski, S., Hoepelman, A.I., Saag, M.S., Goebel, F.D., Rockstroh, J.K., Dezube, B.J., Jenkins, T.M., Medhurst, C., Sullivan, J.F., Ridgway, C., Abel, S., James, I.T., Youle, M., van der Ryst, E., 2005. Efficacy of short-term monotherapy with maraviroc, a new CCR5 antagonist, in patients infected with HIV-1. Nat. Med. 11, 1170-1172.

Feng, Y., Broder, C.C., Kennedy, P.E., Berger, E.A., 1996. HIV-1 entry cofactor: functional cDNA cloning of a seven-transmembrane, $G$ proteincoupled receptor. Science 272, 872-877.

Fouchier, R.A., Groenink, M., Kootstra, N.A., Tersmette, M., Huisman, H.G., Miedema, F., Schuitemaker, H., 1992. Phenotype-associated sequence variation in the third variable domain of the human immunodeficiency virus type 1 gp120 molecule. J. Virol. 66, 3183-3187.

Franti, M., Ramos, L., Maloveste, S., Geerdes, D., Nagashima, K.A., Ketas, T., Delgado, K., Maddon, P.J., Olson, W.C., Poignard, P., (Abstract book) 2004. Control of HIV-1 replication in the hu-PBL-SCID mouse model by an anti-CCR5 monoclonal antibody. In: 11th Conference on Retroviruses and Opportunistic Infections, San Fransisco, USA, p. 257.

Glushakova, S., Yi, Y., Grivel, J.C., Singh, A., Schols, D., De Clercq, E., Collman, R.G., Margolis, L., 1999. Preferential coreceptor utilization and cytopathicity by dual-tropic HIV-1 in human lymphoid tissue ex vivo. J. Clin. Invest. 104, R7-R11.

Gordon, C.J., Muesing, M.A., Proudfoot, A.E., Power, C.A., Moore, J.P., Trkola, A., 1999. Enhancement of human immunodeficiency virus type 1 infection by the CC-chemokine RANTES is independent of the mechanism of virus-cell fusion. J. Virol. 73, 684-694.

Hamy, F., Felder, E.R., Heizmann, G., Lazdins, J., Aboul-ela, F., Varani, G., Karn, J., Klimkait, T., 1997. An inhibitor of the Tat/TAR RNA interaction that effectively suppresses HIV-1 replication. Proc. Natl. Acad. Sci. U.S.A. $94,3548-3553$.

Hatse, S., Princen, K., Gerlach, L.-O., Bridger, G., Henson, G., De Clercq, E., Schwartz, T.W., Schols, D., 2001. Identification of Asp ${ }^{171}$ and $\mathrm{Asp}^{262}$ of the chemokine receptor CXCR4 as crucial interaction sites for HIV1 gp120 and the bicyclam derivative AMD3100. Mol. Pharmacol. 60, 164-173.

Hatse, S., Princen, K., Bridger, G., De Clercq, E., Schols, D., 2002. Chemokine receptor inhibition by AMD3100 is strictly confined to CXCR4. FEBS Lett. 527, 255-262.

Hendrix, C.W., Flexner, C., MacFarland, R.T., Giandomenico, C., Fuchs, E.J., Redpath, E., Bridger, G., Henson, G.W., 2000. Pharmacokinetics and safety of AMD-3100, a novel antagonist of the CXCR-4 chemokine receptor, in human volunteers. Antimicrob. Agents Chemother. 44, 1667-1673.

Hendrix, C.W., Collier, A.C., Lederman, M.M., Schols, D., Pollard, R.B., Brown, S., Jackson, J.B., Coombs, R.W., Glesby, M.J., Flexner, C.W., Bridger, G.J., Badel, K., MacFarland, R.T., Henson, G.W., Calandra, G., AMD3100 HIV Study Group, 2004. Safety, pharmacokinetics, and antiviral activity of AMD3100, a selective CXCR4 receptor inhibitor, in HIV-1 infection. J. Acquir. Immune Defic. Syndr. 37, 1253-1262.

Hu, Q.X., Barry, A.P., Wang, Z.X., Connolly, S.M., Peiper, S.C., Greenberg, M.L., 2000. Evolution of the human immunodeficiency virus type 1 envelope during infection reveals molecular corollaries of specificity for coreceptor utilization and AIDS pathogenesis. J. Virol. 74, 11858-11872.

Ichiyama, K., Yokoyama-Kumakura, S., Tanaka, Y., Tanaka, R., Hirose, K., Bannai, K., Edamatsu, T., Yanaka, M., Niitani, Y., Miyano-Kurosaki, N., Takaku, H., Koyanagi, Y., Yamamoto, N., 2003. A duodenally absorbable CXC chemokine receptor 4 antagonist, KRH-1636, exhibits a potent and selective anti-HIV-1 activity. Proc. Natl. Acad. Sci. U.S.A. 100, 4185-4190.

Jekle, A., Schramm, B., Jayakumar, P., Trautner, V., Schols, D., De Clercq, E., Mills, J., Crowe, S.M., Goldsmith, M.A., 2002. Coreceptor phenotype of natural human immunodeficiency virus with nef deleted evolves in vivo, leading to increased virulence. J. Virol. 76, 6966-6973.

Jekle, A., Keppler, O.T., De Clercq, E., Schols, D., Weinstein, M., Goldsmith, M.A., 2003. In vivo evolution of human immunodeficiency virus type 1 toward increased pathogenicity through CXCR4-mediated killing of uninfected CD4 T cells. J. Virol. 77, 5846-5854.
Joao, H.C., De Vreese, K., Pauwels, R., De Clercq, E., Henson, G.W., Bridger, G.J., 1995. Quantitative structural activity relationship study of bis-tetraazacyclic compounds. A novel series of HIV-1 and HIV-2 inhibitors. J. Med. Chem. 38, 3865-3873.

Kelly, M.D., Naif, H.M., Adams, S.L., Cunningham, A.L., Lloyd, A.R., 1998. Dichotomous effects of beta-chemokines on HIV replication in monocytes and monocyte-derived macrophages. J. Immunol. 160, 3091-3095.

Lederman, M.M., Veazey, R.S., Offord, R., Mosier, D.E., Dufour, J., Mefford, M., Piatak Jr., M., Lifson, J.D., Salkowitz, J.R., Rodriguez, B., Blauvelt, A., Hartley, O., 2004. Prevention of vaginal SHIV transmission in rhesus macaques through inhibition of CCR5. Science 306, 485-487.

Liu, R., Paxton, W.A., Choe, S., Ceradini, D., Martin, S.R., Horuk, R., MacDonald, M.E., Stuhlmann, H., Koup, R.A., Landau, N.R., 1996. Homozygous defect in HIV-1 coreceptor accounts for resistance of some multiply-exposed individuals to HIV-1 infection. Cell 86, 367-377.

Mack, M., Luckow, B., Nelson, P.J., Cihak, J., Simmons, G., Clapham, P.R., Signoret, N., Marsh, M., Stangassinger, M., Borlat, F., Wells, T.N., Schlondorff, D., Proudfoot, A.E., 1998. Aminooxypentane-RANTES induces CCR5 internalization but inhibits recycling: a novel inhibitory mechanism of HIV infectivity. J. Exp. Med. 187, 1215-1224.

Maeda, K., Yoshimura, K., Shibayama, S., Habashita, H., Tada, H., Sagawa, K., Miyakawa, T., Aoki, M., Fukushima, D., Mitsuya, H., 2001. Novel low molecular weight spirodiketopiperazine derivatives potently inhibit R5 HIV-1 infection through their antagonistic effects on CCR5. J. Biol. Chem. 276, 35194-35200.

Maeda, K., Nakata, H., Miyakawa, T., Ogata, H., Koh, Y., Shibayama, S., Sagawa, K., Takaoka, Y., Moravek, J., Koyanagi, Y., Mitsuya, H., 2003. AK602: a novel HIV-specific spirodiketopiperazine CCR5 inhibitor potent against a wide spectrum of R5-HIV. In: 10th Conference on Retroviruses and Opportunistic Infections, p. 61 (Abstract book).

Marechal, V., Arenzana-Seisdedos, F., Heard, J.M., Schwartz, O., 1999. Opposite effects of SDF-1 on human immunodeficiency virus type 1 replication. J. Virol. 73, 3608-3615.

Marozsan, A.J., Torre, V.S., Johnson, M., Ball, S.C., Cross, J.V., Templeton, D.J., Quinones-Mateu, M.E., Offord, R.E., Arts, E.J., 2001. Mechanisms involved in stimulation of human immunodeficiency virus type 1 replication by aminooxypentane RANTES. J. Virol. 75, 8624-8638.

Marozsan, A.J., Kuhmann, S.E., Morgan, T., Herrera, C., Rivera-Troche, E., Xu, S., Baroudy, B.M., Strizki, J., Moore, J.P., 2005. Generation and properties of a human immunodeficiency virus type 1 isolate resistant to the small molecule CCR5 inhibitor, SCH-417690 (SCH-D). Virology 338, 182-199.

Menten, P., Struyf, S., Schutyser, E., Wuyts, A., De Clercq, E., Schols, D., Proost, P., Van Damme, J., 1999. The LD78 $\beta$ isoform of MIP- $1 \alpha$ is the most potent CCR5 agonist and HIV-1-inhibiting chemokine. J. Clin. Invest. 104, R1-R5.

Michael, N.L., Nelson, J.A., KewalRamani, V.N., Chang, G., O’Brien, S.J., Mascola, J.R., Volsky, B., Louder, M., White 2nd., G.C., Littman, D.R., Swanstrom, R., O'Brien, T.R., 1998. Exclusive and persistent use of the entry coreceptor CXCR4 by human immunodeficiency virus type 1 from a subject homozygous for CCR5 delta32. J. Virol. 72, 6040-6047.

Mosier, D.E., Picchio, G.R., Gulizia, R.J., Sabbe, R., Poignard, P., Picard, L., Offord, R.E., Thompson, D.A., Wilken, J., 1999. Highly potent RANTES analogues either prevent CCR5-using human immunodeficiency virus type 1 infection in vivo or rapidly select for CXCR4-using variants. J. Virol. 73, 3544-3550.

Murakami, T., Nakajima, T., Koyanagi, Y., Tachibana, K., Fujii, N., Tamamura, H., Yoshida, N., Waki, M., Matsumoto, A., Yoshie, O., Kishimoto, T., Yamamoto, N., Nagasawa, T., 1997. A small molecule CXCR4 inhibitor that blocks T cell line-tropic HIV-1 infection. J. Exp. Med. 186, 1389-1393.

Murphy, P.M., 2002. International Union of Pharmacology. XXX. Update on chemokine receptor nomenclature. Pharmacol. Rev. 54, 227-229.

Naif, H.M., Cunningham, A.L., Alali, M., Li, S., Nasr, N., Buhler, M.M., Schols, D., De Clercq, E., Stewart, G.J., 2002. A human immunodeficiency virus type 1 isolate from an infected person homozygous for CCR5delta32 exhibits dual tropism by infecting macrophages and MT2 cells via CXCR4. J. Virol. 76, 3114-3124. 
Napier, C., Dorr, P., Gladue, R., Halliday, R., Leishman, D., Machin, I., Mitchell, R., Nedderman, A., Perros, M., Roffeey, S., Walker, D., Webster, R., 2003. The preclinical pharmacokinetics and safety pharmacology of the anti-HIV CCR5 antagonist, UK-427857. In: 10th Conference on Retroviruses and Opportunistic Infections, Boston, USA, p. 251 (Abstract book).

Nichols, W., Steel, H., Bonny, T., Min, S., Curtis, L., Kabeya, K., Clumeck, N., 2005. Hepatoxicity observed in clinical trials of aplaviroc (APL, 873140). In: First International Workshop. Targeting HIV Entry, 2-3 December, Bethesda, MD, USA (Abstract 26).

Oberlin, E., Amara, A., Bachelerie, F., Bessia, C., Virelizier, J.L., ArenzanaSeisdedos, F., Schwartz, O., Heard, J.M., Clark-Lewis, I., Legler, D.F., Loetscher, M., Baggiolini, M., Moser, B., 1996. The CXC chemokine SDF-1 is the ligand for LESTR/fusin and prevents infection by T-cellline-adapted HIV-1. Nature 382, 833-835.

Olson, W.C., Rabut, G.E., Nagashima, K.A., Tran, D.N., Anselma, D.J., Monard, S.P., Segal, J.P., Thompson, D.A., Kajumo, F., Guo, Y., Moore, J.P., Maddon, P.J., Dragic, T., 1999. Differential inhibition of human immunodeficiency virus type 1 fusion, gp120 binding, and CC-chemokine activity by monoclonal antibodies to CCR5. J. Virol. 73, 4145-4155.

Olson, W.C., Doshan, H., Zhan, C., Mezzatesta, J., Assuma, A., Czarnecky, R., Stavola, J., Maddon, P., Kremer, A., Israel, R., 2006. Prolonged coating of CCR5 lymphocytes by PRO 140 a humanized CCR5 monoclonal antibody for HIV-1 therapy. In: 13th Conference on Retroviruses and Opportunistic Infection, Denver, February 5-8 (Abstract 515).

Penn, M.L., Grivel, J.C., Schramm, B., Goldsmith, M.A., Margolis, L., 1999. CXCR4 utilization is sufficient to trigger $\mathrm{CD}^{+}{ }^{+} \mathrm{T}$ cell depletion in HIV1-infected human lymphoid tissue. Proc. Natl. Acad. Sci. U.S.A. 96, 663-668.

Princen, K., Hatse, S., Vermeire, K., Aquaro, S., De Clercq, E., Gerlach, L.O., Rosenkilde, M., Schwartz, T.W., Skerlj, R., Bridger, G., Schols, D., 2004. Inhibition of human immunodeficiency virus replication by a dual CCR5/CXCR4 antagonist. J. Virol. 78, 12996-13006.

Proost, P., De Meester, I., Schols, D., Struyf, S., Lambeir, A.M., Wuyts, A., Opdenakker, G., De Clercq, E., Sharpé, S., Van Damme, J., 1998. Amino-terminal truncation of chemokines by CD26/dipeptidyl-peptidase IV. Conversion of RANTES into a potent inhibitor of monocyte chemotaxis and HIV-1-infection. J. Biol. Chem. 273, 7222-7227.

Proudfoot, A.E., Power, C.A., Hoogewerf, A.J., Montjovent, M.O., Borlat, F., Offord, R.E., Wells, T.N., 1996. Extension of recombinant human RANTES by the retention of the initiating methionine produces a potent antagonist. J. Biol. Chem. 271, 2599-2603.

Reynes, J., Rouzier, R., Kanouni, T., Baillat, V., Baroudy, B., Keung, A., Hogan, C., Markowitz, M., Laughlin, M., 2002a. SCH C: Safety and antiviral effects of a CCR5 receptor antagonist in HIV-1 infected subjects. In: Ninth Conference on Retroviruses and Opportunistic Infections, Seattle, USA, p. 53 (Abstract book).

Reynes, J., Rouzier, R., Kanouni, T., 2002b. SCH C: Safety and antiviral effects of a CCR5 receptor antagonist in HIV-1 infected subjects. In: Ninth Conference on Retroviruses and Opportunistic Infections, February 24-28, Seattle, WA, USA (Abstract 1).

Samson, M., Libert, F., Doranz, B.J., Rucker, J., Liesnard, C., Farber, C.M., Saragosti, S., Lapoumeroulie, C., Cognaux, J., Forceille, C., Muyldermans, G., Verhofstede, C., Burtonboy, G., Georges, M., Imai, T., Rana, S., Yi, Y., Smyth, R.J., Collman, R.G., Doms, R.W., Vassart, G., Parmentier, M., 1996. Resistance to HIV-1 infection in caucasian individuals bearing mutant alleles of the CCR- 5 chemokine receptor gene. Nature $382,722-725$.

Scarlatti, G., Tresoldi, E., Bjorndal, A., Fredriksson, R., Colognesi, C., Deng, H.K., Malnati, M.S., Plebani, A., Siccardi, A.G., Littman, D.R., Fenyo, E.M., Lusso, P., 1997. In vivo evolution of HIV-1 co-receptor usage and sensitivity to chemokine-mediated suppression. Nat. Med. 3, 1259-1265.

Schols, D., Esté, J.A., Henson, G., De Clercq, E., 1997a. Bicyclams, a class of potent anti-HIV agents, are targeted at the HIV coreceptor fusin/CXCR-4. Antiviral Res. 35, 147-156.

Schols, D., Struyf, S., Van Damme, J., Esté, J.A., Henson, G., De Clercq, E., 1997b. Inhibition of T-tropic HIV strains by selective antagonization of the chemokine receptor CXCR4. J. Exp. Med. 186, 1383-1388.
Schols, D., Proost,.P., Struyf, S., Wuyts, A., De Meester, I., Sharpé, S., Van Damme, J., De Clercq, E., 1998a. CD26-processed RANTES(3-68), but not intact RANTES, has potent anti-HIV-1 activity. Antiviral Res. 39, 175-187.

Schols, D., Esté, J.A., Cabrera, C., De Clercq, E., 1998b. T-tropic human immunodeficiency virus type 1 that is made resistant to stromal cellderived factor $1 \alpha$ contains mutations in the envelope gp120 but does not show switch in coreceptor use. J. Virol. 72, 4032-4037.

Schols, D., Claes, S., De Clercq, E., Hendrix, C., Bridger, G., Calandra, G., Henson, G.W., Fransen, S., Huang, W., Whitcomb, J.M., Petropoulos, C.J., AMD-3100 HIV Study Group, (Abstract 2) 2002. AMD-3100, a CXCR4 antagonist, reduced HIV viral load and X4 virus levels in humans. In: Ninth Conference on Retroviruses and Opportunistic Infections, February 24-28, Seattle, WA, USA.

Schols, D., Claes, S., Hatse, S., Princen, K., Vermeire, K., De Clercq, E., Skerlj, R., Bridger, G., Calandra, G., 2003. Anti-HIV activity profile of AMD070, an orally bioavailable CXCR4 antagonist. In: 10th Conference on Retroviruses and Opportunistic Infections, Boston, USA, p. 257 (Abstract book).

Schramm, B., Penn, M.L., Speck, R.F., Chan, S.Y., De Clercq, E., Schols, D., Connor, R.I., Goldsmith, M.A., 2000. Viral entry through CXCR4 is a pathogenic factor and therapeutic target in human immunodeficiency virus type 1 disease. J. Virol. 74, 184-192.

Schurmann, D., Rouzier, R., Nougarede, R., Reynes, J., Fatkenheuer, G., Raffi, F., Michelet, C., Tarral, A., Hoffmann, C., Kiunke, J., Sprenger, H., vanLier, J., Sansone, A., Jackson, M., Laughlin, M., 2004. SCH-D: Antiviral activity of CCR5 receptor antagonist. In: 11th Conference on Retroviruses and Opportunistic Infections, San Fransisco, USA, p. 128 (Abstract book).

Simmons, G., Clapham, P.R., Picard, L., Offord, R.E., Rosenkilde, M.M., Schwartz, T.W., Buser, R., Wells, T.N., Proudfoot, A.E., 1997. Potent inhibition of HIV-1 infectivity in macrophages and lymphocytes by a novel CCR5 antagonist. Science 276, 276-279.

Stone, N., Dunaway, S., Flexner, C., Calandra, G., Wiggins, I., Conley, J., Synder, S., Tierney, C., Hendrix, C., the Adult ACTG A51191 Study Group, 2005. Biologic Activity of an orally bioavailable CXCR4 antagonist in human subjects. In: 15th International AIDS Conference, Bangkok, Thailand.

Strizki, J.M., Xu, S., Wagner, N.E., Wojcik, L., Liu, J., Hou, Y., Endres, M., Palani, A., Shapiro, S., Clader, J.W., Greenlee, W.J., Tagat, J.R., McCombie, S., Cox, K., Fawzi, A.B., Chou, C.C., Pugliese-Sivo, C., Davies, L., Moreno, M.E., Ho, D.D., Trkola, A., Stoddart, C.A., Moore, J.P., Reyes, G.R., Baroudy, B.M., 2001. SCH-C (SCH 351125), an orally bioavailable, small molecule antagonist of the chemokine receptor CCR5, is a potent inhibitor of HIV-1 infection in vitro and in vivo. Proc. Natl. Acad. Sci. U.S.A. 98, 12718-12723.

Strizki, J.M., Tremblay, C., Xu, S., Wojcik, L., Wagner, N., Gonsiorek, W., Hipkin, R.W., Chou, C.C., Pugliese-Sivo, C., Xiao, Y., Tagat, J.R., Cox, K., Priestley, T., Sorota, S., Huang, W., Hirsch, M., Reyes, R.G., Baroudy, B.M., 2005. Discovery and characterization of vicriviroc ( $\mathrm{SCH}$ 417690), A CCR5 antagonist with potent activity against human immunodeficiency virus type 1. Antimicrob. Agents Chemother. 49, 49114919.

Sumner-Smith, M., Zheng, Y., Zhang, Y.P., Twist, E.M., Climie, S.C., 1995. Antiherpetic activities of $\mathrm{N}$-alpha-acetyl-nona-D-arginine amide acetate. Drugs Exp. Clin. Res. 21, 1-6.

Takashima, K., Miyake, H., Kanzaki, N., Tagawa, Y., Wang, X., Sugihara, Y., Iizawa, Y., Baba, M., 2005. Highly potent inhibition of human immunodeficiency virus type 1 replication by TAK-220, an orally bioavailable small-molecule CCR5 antagonist. Antimicrob. Agents Chemother. 49, 3474-3482.

Tamamura, H., Xu, Y., Hattori, T., Zhang, X., Arakaki, R., Kanbara, K., Omagari, A., Otaka, A., Ibuka, T., Yamamoto, N., Nakashima, H., Fujii, N., 1998. A low-molecular-weight inhibitor against the chemokine receptor CXCR4: a strong anti-HIV peptide T140. Biochem. Biophys. Res. Commun. 253, 877-882

Townson, J.R., Graham, G.J., Landau, N.R., Rasala, B., Nibbs, R.J., 2000. Aminooxypentane addition to the chemokine macrophage inflammatory 
protein-1alpha P increases receptor affinities and HIV inhibition. J. Biol. Chem. 275, 39254-39261.

Trkola, A., Dragic, T., Arthos, J., Binley, J.M., Olson, W.C., Allaway, G.P., Cheng-Mayer, C., Robinson, J., Maddon, P.J., Moore, J.P., 1996. CD4-dependent, antibody-sensitive interactions between HIV-1 and its co-receptor CCR-5. Nature 384, 184-187.

Trkola, A., Gordon, C., Matthews, J., Maxwell, E., Ketas, T., Czaplewski, L., Proudfoot, A.E., Moore, J.P., 1999. The CC-chemokine RANTES increases the attachment of human immunodeficiency virus type 1 to target cells via glycosaminoglycans and also activates a signal transduction pathway that enhances viral infectivity. J. Virol. 73, 6370-6379.

Trkola, A., Ketas, T.J., Nagashima, K.A., Zhao, L., Cilliers, T., Morris, L., Moore, J.P., Maddon, P.J., Olson, W.C., 2001. Potent, broad-spectrum inhibition of human immunodeficiency virus type 1 by the CCR5 monoclonal antibody PRO 140. J. Virol. 75, 579-588.

Trkola, A., Kuhmann, S.E., Strizki, J.M., Maxwell, E., Ketas, T., Morgan, T., Pugach, P., Xu, S., Wojcik, L., Tagat, J., Palani, A., Shapiro, S., Clader,
J.W., McCombie, S., Reyes, G.R., Baroudy, B.M., Moore, J.P., 2002. HIV-1 escape from a small molecule, CCR5-specific entry inhibitor does not involve CXCR4 use. Proc. Natl. Acad. Sci. U.S.A. 99, 395-400.

van der Ryst, E., Fatkenheuer, G., Pozniak, A., Johnson, M., Plettenberg, A., Staszewski, S., Hoepelman, I., Saag, M.M., Goebel, F., Rockstroh, J., Dezube, B., Medhurst, C., Sullivan, J., Ridgway, C., Abel, S., Youle, M., Jenkins, T., 2005. Maraviroc (UK-427,857), a novel CCR5 antagonist, demonstrates antiviral activity during 10 day monotherapy studies. In: First International Workshop. Targeting HIV Entry, 2-3 December, Bethesda, MD, USA (Abstract 28).

Wu, L., Gerard, N.P., Wyatt, R., Choe, H., Parolin, C., Ruffing, N., Borsetti, A., Cardoso, A.A., Desjardin, E., Newman, W., Gerard, C., Sodroski, J., 1996. CD4-induced interaction of primary HIV-1 gp120 glycoproteins with the chemokine receptor CCR-5. Nature 384, 179-183.

Zhou, N., Fang, J., Acheampong, E., Mukhtar, M., Pomerantz, R.J., 2003. Binding of ALX40-4C to APJ, a CNS-based receptor, inhibits its utilization as a co-receptor by HIV-1. Virology 312, 196-203. 